\title{
THE BIRTH OF THE PRINCIPLE OF NATIONAL TREATMENT IN COPYRIGHT LAW
}

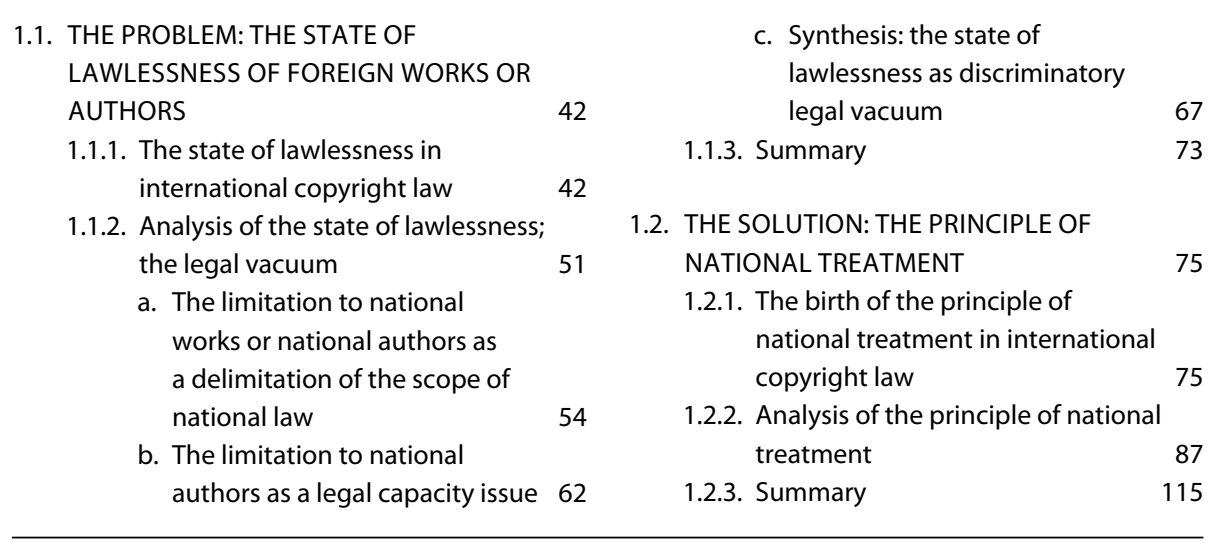

Problem and solution in Chapter 1. The principle of national treatment was developed in international intellectual property law, specifically copyright law, in the first half of the nineteenth century. It was the solution to a historically grown situation that was gradually perceived as problematic, namely the situation of complete lawlessness in which foreign works or foreign authors usually found themselves. To understand this solution (the principle of national treatment, section 1.2), we will first have to focus on the problem (lawlessness, section 1.1).

\subsection{THE PROBLEM: THE STATE OF LAWLESSNESS OF FOREIGN WORKS OR AUTHORS}

1.1.1. The state of lawlessness in international copyright law

Origin of copyright. Like other intellectual property rights, copyright is a rela42 tively young right. Its roots go back to the invention of printing in Europe in 
the fifteenth century. ${ }^{1}$ Various interests converged: printers and publishers, for example, had an interest in protecting the often considerable investments involved in a publication; monarchs and other rulers sought means of censuring works that were not desirable - an aspiration that was often motivated by the desire to prevent the spread of new religious ideas (Reformation). ${ }^{2}$ And, under the influence of the spirit of Renaissance and humanism, authors gradually stepped out of their medieval anonymity and became increasingly aware of their authorship.

43 System of privileges. In these circumstances those in power began to grant privileges against reprinting, initially only to printers and publishers, later also to authors. These privileges usually included the exclusive right to reproduce and distribute a work for a certain period within the territory of the ruler who had granted the privilege. Reprinting was usually punished by sanctions such as confiscation, fines and sometimes damages. ${ }^{3}$ In practice, however, effective protection often left much to be desired: reprinting and plagiarism were the rule rather than the exception. ${ }^{4}$

44 Granting of privileges. A general rule on the granting of privileges cannot be given. The ruler granted them on an individual basis, by way of favour. Even so, a number of main points can be identified. ${ }^{5}$ For example, privileges were frequently not only reserved for their own subjects; they were also granted to foreigners, but usually only for works the foreign author had produced in the country of the ruler in question. ${ }^{6}$ Works that had been published abroad for the first time were usually not eligible for protection under a privilege and were therefore outlawed. ${ }^{7}$ Darras reports that the practice at the time could be summed up in the following rule of thumb: 'Depuis qu'un livre a été une fois publié ou imprimé hors du royaume, aucun ne peut obtenir un privilège particulier pour l'imprimer en ce royaume.' ${ }^{8}$ This general principle was based on political and economic interests, since it enabled a country to favour its own

1 On the history of copyright, see De Beaufort 1909, and Darras 1887; Ladas 1938, p. 12 et seq.; Dock 1963; Khadjavi-Goutard 1977, p. 1 et seq.; Ulmer 1980, p. 50 et seq.; Stewart 1989, p. 13 et seq.; Strömholm 1990, p. 3 et seq.; Seignette 1994, p. 7 et seq.

2 Darras 1887, p. 169; Stewart 1989, p. 15.

3 Stewart 1989, p. 16.

4 For example, Luther complained about reprinting practices in 1525, speaking about street robbers and thieves, see Kok 1905, pp. 16-17.

5 Cf. Darras 1887, p. 173.

6 Darras 1887 , p. 173 et seq.

7 Darras 1887, pp. 170-190.

8 Darras 1887, pp. 174-175. 
industry in particular, that is its own publishers and printers. ${ }^{9}$ In this way, a 'nationality' was attributed to the work, as it were: it bore the nationality of the country where it was first published. ${ }^{10}$

System of privileges in the Netherlands. A system of privileges also existed in the Netherlands. ${ }^{11}$ In practice, however, the protection against reprinting was too weak in this country. ${ }^{12}$ Especially in the seventeenth century, Dutch publishers and printers experienced golden times, mainly thanks to French authors. On the one hand, the Netherlands was a safe haven because of its relatively large freedom of printing, but on the other hand, it was a notorious reprinting centre. ${ }^{13}$

Statutory copyright. The system of privileges persisted in most countries until the eighteenth century. Gradually, pressure increased to recognize and protect the author's rights by law. The first Copyright Act came into force in England in 1710, followed by copyright laws in Denmark and in some American states. In France, the French Revolution brought legal recognition of copyright. In its wake, in the first half of the nineteenth century, copyright was also put on a statutory basis in large parts of continental Europe, ${ }^{14}$ including - though at a relatively late stage - the Netherlands. ${ }^{15}$

Limitation to protection in national laws; two systems. These national copyright laws broadly echoed the tone already set in the era of privileges: national interests dictated a limitation of protection. In this context, two main lines are visible. ${ }^{16}$ In some countries, protection under copyright law was limited to works by national authors. ${ }^{17}$ For example, the American Copyright Act provided only protection in the United States of works by national authors,

9 Darras 1887, p. 178; in a detailed fashion: Briggs 1906, p. 82 et seq. Cf. also Foelix 1844, p. 761.

10 Darras 1887, pp. 176-178.

11 Cf. De Beaufort 1909, p. 4 et seq.; Van den Velden 1835; Romberg 1859, Tome II, pp. 192-196; Van de Kasteele 1885, pp. 36-49; Lyon-Caen and Delalain 1889, Tome I, p. 457; Kok 1905, p. 17 et seq. The first privilege in the Low Countries seems to have been granted in 1516 (De Beaufort 1909, p. 4).

12 This is illustrated by a remark made in 1660 by the Dutch poet and playwright Vondel, who had become the victim of reprinting: 'Tegens deze ongeschicktheit, en moetwillige boosheit schieten my geene wapens dan mijn gedult over.' ['In the face of this unsuitability and wilful malice, I have no weapons but my patience.'] (see Van Lennep 1864, p. 144).

13 Darras 1887, p. 140 et seq.; Ladas 1938, pp. 16-17. A well-known observation made by Voltaire is that Dutch booksellers earn one million a year because the French are quick-witted (see De Beaufort 1909, p. 32).

14 Ladas 1938, p. 19.

15 De Beaufort 1909 , p. 31 and p. 39 et seq.

16 Cf. Briggs 1906, p. 57 et seq.; Ladas 1938, pp. 31-33.

17 Ladas 1938, pp. 21 and 33. Protection was also granted to foreign authors who were resident in the United States. 
wherever these were published. However, most national copyright laws provided that they applied only to national works, i.e. to works first published domestically ('national works'), irrespective of the author's nationality. In the Netherlands, for example, foreign works were not protected, even if the author was a Dutch national. ${ }^{18}$ Protection was therefore limited either to works of national authors or to national works. ${ }^{19}$ In this context, this was referred to as 'le système de la nationalité de l'auteur' and 'le système de la nationalité de l'œuvre'. ${ }^{20}$ The combination of these limitations also occurred; the protection was then limited to national works written by national authors.

48 Dominant system: limitation to works. The limitation to national works predominated, however. This limitation was the most obvious one:

for, while it is undoubtedly of advantage to a State to secure the publication of as many works as possible within its dominions, the publication of works abroad by its subjects or persons domiciled in it results in no gain whatever to its literature. As long as the country obtains the work, the nationality of the author matters little. ${ }^{21}$

In practice, however, a distinction in this respect was of a more theoretical nature in those days - authors usually published their works in their own country for the first time. ${ }^{22}$ In fact, a limitation to national works meant a limitation to works by a country's own authors and vice versa. For this reason, the present study considers discrimination against foreign works to be part of the law of aliens, although strictly speaking, the law of aliens relates only to persons and not to objects. This is a historically grown peculiarity in international copyright law. ${ }^{23}$

18 For example, under Art. 6 of the Copyright Act of 25 January 1817 (Stb. 1817, 5), it was assumed that there was freedom to 'reprint the works published in a foreign country in the Netherlands', except as provided for in a treaty (according to the judgment of the Amsterdam District Court of 12 January 1848, Regtsgeleerd bijblad 1848, Part X, p. 560). The Copyright Act of 28 June 1881 (Stb. 1881, 124) did not change this fundamentally (art. 27). See, inter alia, Van den Velden 1835, pp. 167-170; Pataille and Huguet 1865, pp. 270-276; Van de Kasteele 1885, p. 157; Darras 1887, p. 349; Bureau de l'Union, DdA 1891, pp. 1-6; Veegens 1895, p. 176; De Beaufort 1909, p. 315; Peremans and Wijnstroom 1930, p. 115.

19 Below, reference will be made, for the sake of brevity, to the protection of foreign authors rather than the protection of works of foreign authors.

20 Ratisbonne, Lermina and Pouillet 1889, pp. 156-157. The latter system was also occasionally referred to as the 'principle of territoriality' because its focus lies on the place of publication (cf. Darras 1887, p. 566; Wauwermans 1894, p. 391; Bureau de l'Union, DdA 1895, p. 163 left column; Röthlisberger 1906, p. 27; Bureau de l'Union, $D d A 1910$, p. 60). This term may lead to confusion, however (cf. e.g. Briggs 1906, p. 186 et seq.).

21 Briggs 1906, p. 187.

22 Cf. Röthlisberger 1906, p. 126. According to the European Court of Justice, this is still the case; see CJEC 30 June 2005, C-28/04, ECLI:EU:C:2005:418 (Tod's v Heyraud) at 24-26.

23 This view is endorsed in the judgment of the European Court of Justice in Tod's v Heyraud; see note 22 of this Chapter 1. As a matter of fact, this peculiarity is not exclusive, cf. e.g. Art. $311 \mathrm{WvK}$ (repealed), which attributed Dutch nationality to certain ships (see Kosters and Dubbink 1962, p. 542). 
State of lawlessness. Protection under national copyright law was thus limited to national works and/or national authors. The foreign work or foreign author was left in a curious state: a state of complete lawlessness. This situation no longer exists today, but it used to be different. Once, in bygone days, complete lawlessness was very common in private law. But in the course of time this phenomenon disappeared and nowadays this state of affairs is no longer possible in private law. In the nineteenth century, however, complete lawlessness in private law had not yet disappeared: although it was no longer common then, it was not an unknown phenomenon. In some areas, such as copyright law, this state of complete lawlessness continued to exist, National political and economic interests were at the root of this, as stated above. ${ }^{24}$ For example, Klostermann made the following observation:

Während längst dem Ausländer gestattet wurde, sein Eigenthum und seine Forderungsrechte im Inlande zu verfolgen, galt für das im Auslande erworbene geistige Eigenthum des Schriftstellers, Künstlers und Erfinders fast vollständige Rechtlosigkeit. Der Grund dieser Erscheinung liegt offenbar darin, dass die Gegenseitigkeit der Verkehrsbeziehungen auf dem Gebiete des geistigen Eigenthumes nicht so offen zu Tage lag, als auf andern Verkehrsgebieten. Das Eigenthum und die Schuldforderungen des Auslandes zu schützen, lehrte das eigene handgreifliche Interesse des inländischen Handels, weil ohne diese Bedingung ein Verkehr mit dem Auslande nicht möglich war. Die Literatur einer fremden Nation unentgeltlich auszubeuten gilt aber noch heute in den Augen gewisser Staatsmänner und Nationalökonomen für angemessen und erlaubt. ${ }^{25}$

Piracy. People reprinted works at will and this became easier and more attractive in the nineteenth century. On the one hand, the progress of technology made it possible to print and distribute ever more quickly and more cheaply. On the other hand, a larger audience arose because education improved and because the press became increasingly important, resulting in more publicity being given to authors and their works. ${ }^{26}$ In some countries international reprints became a very lucrative business. In the Netherlands and Belgium, for example, a flourishing industry emerged. ${ }^{27}$ The author of the reprinted work was hardly taken into account, and people did not seem to think there was anything wrong with that attitude. ${ }^{28}$ For example, in 1835 Van der Velden

24 See para. 44 above. The Dutch Copyright Act of 25 January 1817 e.g. was very explicit about this: there was an explicit requirement that the work 'should be printed in a Dutch printing office' and should have 'a Dutch publisher' (Art. 6).

25 Klostermann 1867, pp. 5-6.

26 Cf. De Beaufort 1909, p. 53.

27 Briggs 1906, pp. 34-56, who also reports that the Dutch king even subsidized international reprints (Briggs 1906, p. 36 and p. 50).

28 Briggs 1906, pp. 36-38. 
considered it 'fair' and 'in accordance with the interests of domestic industry' that protection under the Dutch Copyright Act of 1817 was limited to national works. ${ }^{29}$

\subsubsection{Analysis of the state of lawlessness; the legal vacuum}

51 Two aspects. This state of complete lawlessness, as it occurred in the first half of the nineteenth century, was the problem for which the principle of national treatment was developed as a solution. Let us therefore take a closer look at this state of affairs. Two aspects can be distinguished.

52 Aliens law: discrimination. On the one hand, this situation has an alienslaw aspect: the foreign work or the foreign author is discriminated against compared to the national work or the national author. Consequently, there is discrimination. The existence of this aliens-law aspect is nowadays undisputed and needs little explanation.

53 Conflict of laws: legal vacuum. On the other hand, this situation also has a conflict-of-law aspect, which is a peculiar phenomenon according to contemporary views: there is no applicable legal system with regard to the protection of the foreign work or the foreign author. Neither national law nor any other law is applicable. This means that there is a 'legal vacuum'. A good understanding of this legal vacuum is crucial, as it provides the key to understanding the conflict-of-law rule in the principle of national treatment. At the same time, this is one of the main reasons why this conflict-of-law rule is no longer understood today: it is because we no longer recognize the legal vacuum in this day and age ${ }^{30}$ Let us therefore focus on the question why there is a legal vacuum. How could this vacuum arise? To answer this question, we must focus on the previously discussed limitation in nearly all nineteenth-century national copyright laws: the limitation to national works or national authors. This limitation could be shaped in two ways: either as a delimitation of the scope of application of national law (section (a)), or as a restriction on the legal capacity of foreigners (section (b)).

29 Van den Velden 1835, pp. 167-170.

30 This will be discussed in section 5.1 .2 below. 


\section{a. The limitation to national works or national authors as a delimitation of the scope of national law}

Delimitation of the scope. Let us first consider the configuration where the limitation to national works or national authors was shaped as a delimitation of the scope of national law. This configuration was the most common in practice. A clear example can be found in Article 27 of the Dutch Copyright Act of 1881:

This Act shall apply to works printed and communicated to the public in the Netherlands or in the Dutch East Indies as well as to works not communicated to the public which originate from authors residing in the Netherlands or in the Dutch East Indies, including speeches held in the Netherlands or in the Dutch East Indies. ${ }^{31}$

Doctrine of statutes. In this configuration there was primarily a conflict-oflaw issue. To gain a better understanding of that, we need to zoom in on the conflict of laws in the first half of the nineteenth century. ${ }^{32}$ At that time the conflict of laws was dominated by the 'doctrine of statutes', also referred to as the 'statute theory'. The modern conflict of laws designed by Von Savigny had not yet been born, as Von Savigny did not make his conflict-of-law model known to the world until 1849. The pre-Savignian statutist conflict-of-law model answered the question of the applicable law by determining the scope of domestic legal rules. In principle, this conflict of laws was unilateral; the primary objective was to define the scope of a country's own rules of law. ${ }^{33}$ Rules of law were divided into a number of classes, and each class was deemed to have a certain scope, which could be deduced from the nature of that class of rules of law. ${ }^{34}$

The principle of formal territoriality. In this context, the 'principle of formal territoriality' formed the generally accepted underlying notion in the eighteenth and nineteenth centuries. According to this principle, the scope of the law is limited to a country's own territory ('material territoriality') and the

31 Art. 27 of the Copyright Act of 28 June 1881.

32 Even though the provision from the Dutch Act of 1881, cited just now as an example, is of a later date, it is a reproduction of its predecessors in the first half of the nineteenth century (cf. also its - less accessible predecessor, Art. 6 of the Dutch Act of 1817). It has been chosen here as an example because of its 'pure' form, i.e. without reciprocity conditions. These conditions, which were laid down in nearly all other copyright laws, constitute a complication which, from a didactic point of view, is not taken into account at this stage of our search; it will be introduced in section 1.2 of this study.

33 If a country's domestic law did not apply on the basis of its own unilateral conflict-of-law rule, then - provided this country's domestic law allowed it - foreign law could be applied on the basis of that same conflict-of-law rule; the conflict-of-law rule was 'bilateralized', or rather, 'generalized'.

34 Strikwerda 1978, p. 113. Cf. also Kegel and Schurig 2004, p. 174. 
court applies only the country's national law ('formal territoriality'). ${ }^{35}$ The formal territoriality principle was based on state sovereignty. ${ }^{36}$ According to this state sovereignty, the legislator can set standards only within its own territory ('material territoriality'); and its enforcement - enforcement, just like legislation, is a sovereign matter - is, in principle, exclusively entrusted to the country's domestic courts (formal territoriality). The exceptions to the principle of formal territoriality, which mainly concerned rules of the law of persons, were justified by the 'comitas' (benevolence) which the states apply to each other. ${ }^{37}$ One could think of the three fundamental rules (axiomata) formulated by Ulrik Huber, the seventeenth-century legal scholar who left his mark on eighteenth-century and nineteenth-century conflict of laws. ${ }^{38}$

57 Scope of copyright laws. In the spirit of the doctrine of statutes in force at the time, how was the scope of the national copyright laws of the time defined? Well, this scope was delimited in three respects. Two delimitations were implicit in the principle of formal territoriality, which also governed intellectual property law, including copyright law. ${ }^{39}$ Under this principle, the scope of copyright laws was first and foremost limited in terms of material territoriality: its protection extended only to the national territory. And second, its scope was limited in terms of formal territoriality: the court had to apply only its own country's copyright law. ${ }^{40}$ The third delimitation was the limitation to national

35 Cf. Strikwerda 1978, p. 5 et seq. The term 'principle of formal territoriality' (which, incidentally, is of a later date) is not an established term of art. In this study the 'principle of formal territoriality' is defined as including both formal territoriality and material territoriality (so not just formal territoriality). This definition is introduced by this study.

36 See, inter alia, authoritative handbooks of the time, such as Foelix 1843, p. 12 et seq. (Foelix v Demangeat 1866, p. 19 et seq.); Story 1841, p. 25 et seq. Cf. also Strikwerda 1978, p. 5. Vogel 1965, pp. 89-90 illustrates how strong the territoriality idea was in those days.

37 Cf. Strikwerda 1978, p. 118.

38 Vogel 1965, p. 35 et seq. These axiomata will be discussed below, in section 5.2.3. Huber first used the principle of formal territoriality as a starting point for the conflict of laws, cf. Vogel 1965, p. 28 et seq.

39 This was self-evident. Copyright was no exception to this general principle. Cf. e.g. Foelix 1843, p. 575, who discusses intellectual property law in the title on 'Des actes illicites de l'homme, ou du droit criminel international' (in those days, 'delicts' or 'torts', which, in our modern eyes, are a private-law concept, and criminal offences were placed on the same level). Cf. also Celliez 1878, pp. 13-14 ('le caractère de lois de police') and Briggs 1906, pp. 34-35.

40 '(...) car c'est dans cette loi seule que le juge puise sa propre jurisdiction et c'est elle seule qu'il est en mesure d'appliquer', as the Italian Corte di cassazione formulated it concisely (Corte di cassazione 14 January 1900, Monitore dei Tribunali, Vol. 41, 1900, II series, vol. 3, pp. 176-177 (Albrecht and Meister v Gualassini), French translation in $D d A 1900$, p. 121; see also note 88 of this Chapter 1). See also e.g. the explanatory memorandum to Art. 28(1) of the Dutch Copyright Act 1881, in which it is observed - as if it were selfevident - that 'the Dutch court can administer justice only by virtue of Dutch law' (Kamerstukken II 1876/77, 202 , no. 3, p. 5). 
works or national authors. National law applied only to works published for the first time in the country's national territory or to works by national authors. ${ }^{41}$

Legal vacuum. The consequence of these delimitations was that foreign works or foreign authors were left in a legal vacuum, because, due to the principle of formal territoriality, they were entirely dependent on domestic law and domestic courts for protection in another country: domestic law was the only law that could be applied in terms of material territoriality, and only domestic courts were allowed to apply that law. And precisely this domestic law applied only to national works or authors, not to foreign works or authors. Thus, as far as the latter were concerned, no law was applicable - hence the legal vacuum.

Combination of three delimitations. For the record, it should be noted that it is the combination of these three delimitations that causes the legal vacuum. Thus, the principle of formal territoriality as such does not create the legal vacuum. Indeed, if only the two delimitations contained in this principle were to apply, the protection of the foreign work or the foreign author would be regulated by domestic law and the domestic courts. From this perspective, it is the further delimitation to national works or authors that creates the legal vacuum. But the delimitation to national works or authors as such does not create the legal vacuum either, because this delimitation - which is a unilateral conflict-of-law rule - does not say anything about foreign works or foreign authors. Whether they will find themselves in a legal vacuum depends on the overall structure of the system. For example, the legal vacuum does not arise if the delimitation to national works or authors is generalized, meaning that it is applied not only to a country's domestic copyright law but also to foreign copyright laws ('generalization', also known as 'bilateralization'). In that case, the protection of the foreign work or author is governed by the latter's own law. ${ }^{42}$ But the legal vacuum does arise if the principle of formal territoriality is added to the delimitation to national works or foreign authors. Viewed from this perspective, it is the further delimitation by the formal territoriality principle that creates the legal vacuum.

41 Usually, this delimitation was formulated in a positive way ('this law shall apply only to works published for the first time within the national territory'). Occasionally, however, the formulation was bluntly negative, as e.g. in Art. 79(2) of the Hungarian Copyright Act of 26 April 1884: 'Auf Werke von Ausländern findet dieses Gesetz keine Anwendung' (Gesetze über das Urheberrecht 1891, p. 113). Incidentally, the exceptions made to this principle are indicative of the political-economic motives: 'Eine Ausnahme bilden und Rechtsschutz geniessen: (a) Jene Werke von Ausländern die bei inländischen Verlegern erschienen sind; (b) Werke jener Ausländer, welche mindestens zwei Jahre im Lande ständig wohnen und hier ununterbrochen Steuer zahlen.'

42 In that case a lex originis conflict-of-law rule has arisen. 


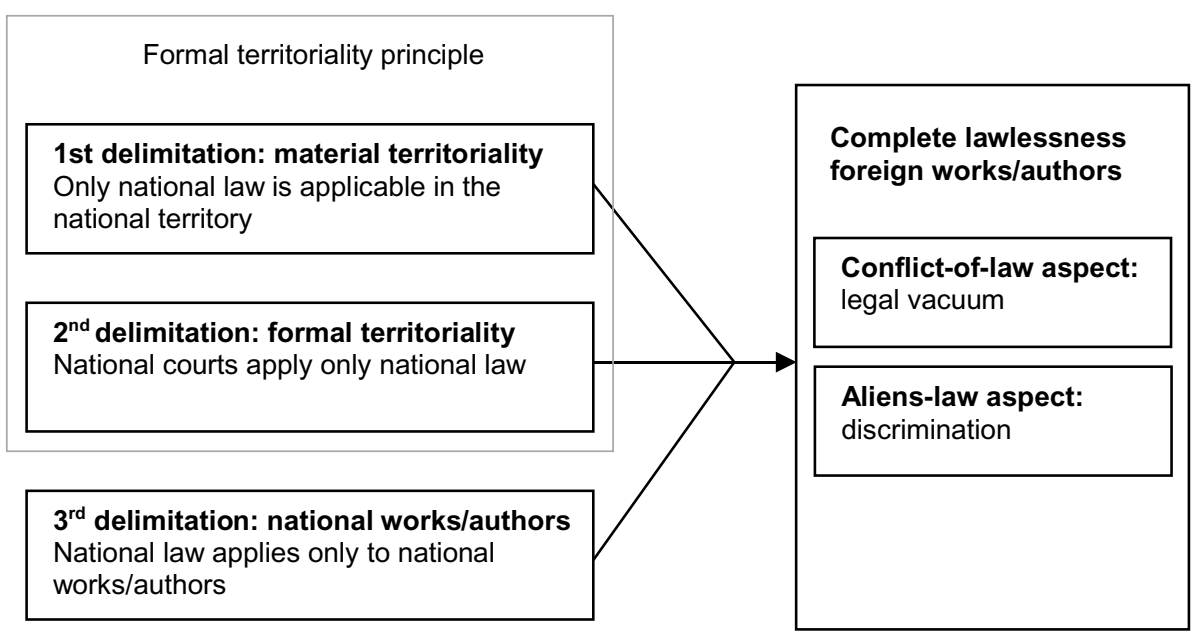

60 Figure 1.1 State of lawlessness and the legal vacuum

61 Diagram. In summary, the legal vacuum was caused by the combination of, on the one hand, the delimitation(s) by the principle of formal territoriality and, on the other hand, the delimitation to national works or national authors. This is shown schematically in Figure 1.1.

\section{b. The limitation to national authors as a legal capacity issue}

62 Legal capacity. In the preceding section we examined the configuration where the limitation to national works or authors was designed as a delimitation of the scope of national law. In addition, as we found earlier, there was the configuration where the limitation to national authors was designed as a restriction on the legal capacity of foreigners. Section 1 of the U.S. Copyright Act of 1831 could be taken as an example:

(...) any person or persons, being a citizen or citizens of the United States, or resident therein, who shall be the author or authors of any book or books, map, chart, or musical composition, (...) shall have the sole right and liberty of printing, reprinting, publishing, and vending such book or books, map, chart, musical composition, (...). ${ }^{43}$

63 Aliens law. This configuration primarily concerns a matter of aliens law. We will take a closer look at this. In long-forgotten days foreigners were not

Section 1 of the Act of 3 February 1831, 4 Stat. 436. Just to be sure, Section 8 explicitly stated:

That nothing in this act shall be construed to extend to prohibit the importation or vending, printing, or publishing, of any map, chart, book, musical composition, print or engraving, written, composed, or made, by any person not being a citizen of the United States, nor resident within the jurisdiction thereof.

The same point was made in Sections 1 and 5 of the first American Copyright Act of 31 May 1790, 1 Stat. 124. 
recognized as participants in private-law transactions. Private law once formed a legal sphere that was not accessible to foreigners. ${ }^{44}$ They had no legal capacity: in other words, a foreigner could not be a bearer of civil rights; indeed, he was simply not a person holding legal rights. In the course of the centuries, foreigners were granted access to the enjoyment (la jouissance) of more and more civil rights; they were granted limited legal capacity. Thus, the gap in legal capacity between a country's own nationals and foreigners gradually narrowed, and nowadays the issue of the foreigner's legal capacity no longer arises; for us it goes without saying that foreigners have full legal capacity. ${ }^{45}$ But in the first half of the nineteenth century this development was not yet completed. ${ }^{46}$ Well-known bottlenecks included inheritance law and the right of ownership of immovable property. ${ }^{47}$

Legal capacity in relation to the conflict of laws. The question of legal capacity is a question that 'historiquement et rationnellement' precedes the question of the applicable law. ${ }^{48}$ It is a preliminary question. ${ }^{49}$ First, we must determine, by reference to our law, whether a foreigner can be a bearer of a particular civil right at all. For example, can a foreigner enjoy property rights in this country? Only after it has been established that a foreigner can be a bearer of a certain right can the question arise as to what legal system governs the issue. See 'les deux questions, qui résument en effet toute notre matière: (1) Quels sont les droits dont jouissent les étrangers en France? (2) Quelle est la loi qui régit les droits reconnus aux étrangers? ${ }^{30}$ Demangeat phrased it as follows:

Et puis ensuite, à mesure qu'on a constaté que notre législation n'exclut pas les étrangers de la jouissance de telle ou telle nature de droits, il reste toujours à se demander

44 Von Frisch 1910; Demangeat 1844; Kosters and Dubbink 1962, p. 543.

45 Cf. Art. 9 of the Dutch General Provisions (Kingdom Legislation) Act and Art. 1:1(1) Burgerlijk Wetboek ['BW'] (Dutch Civil Code).

46 Von Wächter 1841, p. 253; Von Savigny 1849, p. 25, is optimistic about the 'Rechtsfähigkeit' of foreigners: 'Das heutige Recht dagegen hat allmälig zur Anerkennung vollständiger Rechtsgleichheit zwischen Einheimischen und Fremden hingeführt.' On p. 114 he writes more cautiously about 'die stets allgemeiner anerkannte gleiche Rechtsfähigkeit unter Inländern und Ausländern'.

47 This is not surprising. For a long time these branches of law held the keys to power and wealth, and countries did not like to hand them over. Inheritance used to be the most important way of acquiring property, while immovable property was the most important asset (land ownership).

48 Audit 2006, p. 15.

49 See also Foelix and Demangeat 1866, p. 12, note (a); Renault 1875, p. 343; Kosters 1917, p. 61; cf. also Kahn 1899 , p. 263 with further references. Specifically in relation to copyright, see, inter alia, Despagnet 1891, p. 91; Bureau de l'Union, DdA 1937 (La condition civile), p. 85. Cf. also Von Savigny 1849, p. 25, who makes the following comment on the 'Rechtsfähigkeit' of foreigners: 'Mit dieser Rechtsgleichheit der Personen ist jedoch über die Frage wegen der Collision zwischen dem einheimischen und fremden Rechte noch gar nicht entschieden.'

50 Durand 1884, p. 212. 
par quelle loi cette faculté, qui au fond est octroyée à l'étranger, devra être réglementée dans ses mains. (. . .)

(. . .) après avoir reconnu qu'un étranger n'est point exclu par la loi française du droit de se marier en France, soit avec une Française soit avec une étrangère, il restera à nous demander quelle loi devra être consultée pour déterminer les conditions d'un pareil mariage, ses conséquences civiles, etc. ${ }^{51}$

65 Legal vacuum. If, on the other hand, the foreigner has no legal capacity in a particular matter, the question of the applicable law does not need to be addressed. The foreigner does not hold any legal rights at all in that case - and that is the end of the matter. Only if he can be the bearer of a particular right can the question of the law applicable to that right arise. ${ }^{52}$ As long as that is not the case, the conflict-of-law question remains unanswered; it remains uncertain which legal system would apply to the case at hand. There is simply no legal system designated as applicable - there is a legal vacuum. ${ }^{53}$ All this is somewhat difficult to imagine these days, because it is self-evident to us that foreigners have full legal capacity and hold legal rights. A contemporary example might make it more understandable for us. Let us compare it to an animal. An animal is not recognized as a person holding legal rights. The question which law applies to the acquisition of property by a German shepherd dog in the Netherlands can therefore not arise - voilà. The comparison sounds harsh and does not quite fit, but it does make it clear what the issue is. ${ }^{54}$

66 Legal incapacity of foreign authors. Let us return to nineteenth-century copyright law. We saw that in some countries the limitation of legal protection to national authors was placed in the context of legal capacity. ${ }^{55}$ This meant that foreigners were not persons holding legal rights in this respect - they could not own copyright at all. Consequently, the question of what copyright law

51 Demangeat 1844 , pp. 317-318.

52 Cf. Marees van Swinderen 1862, p. 11:

Because once the principle had been adopted that a foreigner was not entirely without rights, the question had to arise as to which law would govern the assessment of his status and rights, the law of the State in which he resided or the law of the State of which the foreigner was a national.

53 For the sake of clarity: although domestic law determines the legal capacity of the foreigner, this does not mean that domestic law - if it recognizes this legal capacity - also applies on a substantive level. Compare the above-mentioned example of Demangeat.

54 According to generally accepted contemporary standards, an animal is, in legal terms, an object, and the position of the foreigner in Europe - at least in recent centuries - was not that poor.

55 Where the legal protection limitation is designed as a restriction on legal capacity, it primarily affects authors rather than works, because a work cannot have legal capacity. In theory, it is conceivable that the legal capacity of foreigners is restricted with respect to works published for the first time in a foreign country. 
applied to the protection of their works was no longer addressed. No law was applicable to the protection; there was a legal vacuum.

\section{c. Synthesis: the state of lawlessness as discriminatory legal vacuum}

Synthesis. Let us combine the above. Virtually all nineteenth-century national copyright laws contained a limitation to national works or national authors. Regardless of how this limitation was designed - as a delimitation of the scope of application of national law or as a restriction on the legal capacity of foreigners $-\mathrm{a}$ legal vacuum arose in both configurations.

First configuration. In the first configuration - a limitation of the scope of national law - there was primarily a conflict-of-law issue, namely a delimitation issue which created a legal vacuum. But it was not only a matter of conflict of laws, because the legal vacuum affected only foreign works or foreign authors. So it was also a matter of discrimination, a matter of aliens law.

Second configuration. The second configuration - a restriction on the legal capacity of foreigners - primarily concerned a matter of aliens law, namely a matter of legal capacity. But this aliens-law matter also involved a conflictof-law aspect. Because the foreigner could not be a bearer of copyright at all, no law was applicable to the protection in respect of him; so there was a legal vacuum, a conflict-of-law matter.

Discriminatory legal vacuum. Accordingly, in both configurations the state of lawlessness has two sides: aliens law (discrimination) and conflict of laws (a legal vacuum). Thus, in both configurations the state of lawlessness was a discriminatory legal vacuum.

Customary configuration. Usually it concerned the first configuration, a delimitation of the scope of national copyright law. ${ }^{56}$ The first obstacle, that of legal capacity, had been overcome in most countries: a foreigner could usually be a copyright owner. ${ }^{57}$ The problems arose from the question that was subsequently posed, that of the applicable law. This question often gave rise to the second obstacle - a 'smart' delimitation of the scope of national law - and a legal vacuum was found to exist after all. In 1878, Renault, an authoritative author who was to be actively involved in the drafting of the Berne Convention,

56 Cf. collections of statutes such as Eisenlohr 1856; Romberg 1859, Tome II; Pataille and Huguet 1865; LyonCaen and Delalain 1889; Gesetze über das Urheberrecht 1891. See also Darras 1887, p. 181 et seq.; Briggs 1906, p. 57 et seq. (cf. also p. 190); Ladas 1938, p. 20 et seq.

57 Cf. Demangeat 1844, pp. 321-322. 
confirmed that in nearly all countries it was indeed not a question of aliens law or legal capacity in particular:

En résumé, dans la doctrine qui avait prévalu, la protection assurée par nos lois aux auteurs avait un caractère exclusivement territorial à un point de vue négatif comme à un point de vue positif, en ce sens que de même qu'on protégerait toutes les œuvres publiées en France, on ne protégeait que celles-là; la loi tenait compte du lieu de la publication. On voit donc que cette théorie n'avait rien de commun avec la question de

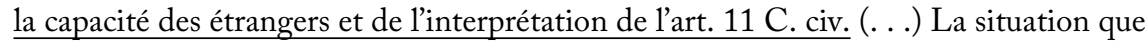
nous venons d'exposer était, sauf des nuances de détail, celle de presque tous les pays. ${ }^{58}$

72 That is to be expected, as we saw before, because countries were usually aiming for as many publications as possible within their own dominions - as this benefited their own industry. ${ }^{59}$ From that perspective, the author's nationality is not important. The rationale was as follows: we reward every author - including a foreigner - who publishes his work in our country. For this reason, a limitation to national authors, such as a restriction on the legal capacity of foreigners, would be less appropriate.

\subsubsection{Summary}

73 State of lawlessness. Let us summarize the above examination into the state of lawlessness. We have found that in the first half of the nineteenth century foreign works or - less often - foreign authors were usually completely unprotected. They were in a state of lawlessness. This situation, which was dictated by national political and economic interests, had grown historically. It had existed since the emergence of copyright in the fifteenth century, when copyright was still granted as a privilege by way of favour, and it continued when copyright became a statutory right around the beginning of the nineteenth century.

74 Analysis of the state of larwlessness. This state of complete lawlessness was sometimes the consequence of a restriction on the legal capacity of foreigners, but usually it was the consequence of a delimitation of the scope of national law - this was the time of the pre-Savignian doctrine of statutes. In either case,

58 Renault 1878, pp. 6-7 (underlining added). Renault was a delegate to the Establishment Conference of the Berne Convention in 1885, the Paris Conference in 1896 and the Berlin Review Conference in 1908. At the Berlin Conference, he was also president and rapporteur of the Commission.

Art. 11 of the French Code civil - which has remained unchanged to date - governs the legal capacity of foreigners: 'L'étranger jouira en France des mêmes droits civils que ceux qui sont ou seront accordés aux Français par les traités de la nation à laquelle cet étranger appartiendra.'

59 See para. 48 above. 
there are two aspects to the state of lawlessness that can be distinguished: there is discrimination (aliens law) and there is a legal vacuum (conflict of laws). In other words, the state of lawlessness was a discriminatory legal vacuum. This state, as will be discussed in the next section, was the problem for which the principle of national treatment was developed as a solution.

\subsection{THE SOLUTION: THE PRINCIPLE OF NATIONAL TREATMENT}

\subsubsection{The birth of the principle of national treatment in international copyright law}

Lawlessness as a problem. The state of complete lawlessness of foreign works or foreign authors became problematic in the first half of the nineteenth century, especially in countries with relevant production levels in the fields of literature and art. These countries had to watch powerlessly as national works and authors lost any legal protection beyond their borders and as these works were reprinted without any restriction. These cheap reprints spoiled not only the foreign market but often the domestic market as well, because reprints were frequently illegally imported. ${ }^{60}$ Understandably, the problem became more acute as international traffic increased exponentially in the nineteenth century, both in speed and size. Darras, for example, reports how in the second half of the nineteenth century American publishers had a newly published book in England telegraphed to America within the space of 24 hours, after which they reprinted it and put it up for sale within 12 hours of the arrival of the last words. ${ }^{61}$ Thus, in the course of the nineteenth century, the state of lawlessness was increasingly perceived as problematic. Gradually the insight dawned that effective copyright protection also needed to be regulated internationally. The state of complete lawlessness was tolerated less and less. Increasingly, people spoke of 'piracy' and pressure to put an end to this situation steadily increased during the nineteenth century.

National treatment as a solution. How was the state of lawlessness terminated? The principle of national treatment (traitement national): provided the key to the solution: to put it briefly, the rightless foreign work or foreign author was

60 Cf. Ladas 1938, p. 25. The problem was all the more pressing within one language area. For example, France experienced the adverse effects of reprinting in Belgium; the United Kingdom of reprinting in the United States and Ireland, and German states of reprinting in Austria; see Briggs 1906, p. 39.

61 Darras 1887, p. 143, note 1; Briggs 1906, p. 40. 
taken under the wing of domestic law. This solution reached maturity in a number of stages. ${ }^{62}$

77 Development stage 1: unilateral legislation. Initially - the first stage - this solution was worked out unilaterally in national legislation. Countries expressed their willingness to give up the limitation to national works or authors subject to the condition of reciprocity. ${ }^{63}$ Roughly speaking, they reasoned as follows: our national law applies to works published abroad, provided that the national law of the relevant foreign country also applies to works published in our country. This gave rise to the principle of national treatment as a 'mirror image' of the usual limitation to national works or authors. Such reciprocity-based provisions, in which there was a conditional principle of national treatment, were found in many nineteenth-century copyright laws.

78 Example: Denmark 1828. The first such principle of national treatment can be found in the Danish ordinance of 7 May 1828, which is therefore regarded as a milestone in international copyright law. ${ }^{64}$ This ordinance made the Danish Copyright Act of 1741 applicable to works of foreign authors, provided that the works of Danish authors were protected in their countries:

(. . .) que la défense contenue dans l'ordonnance du 7 janvier 1741 contre la contrefaçon, mais qui a spécialement égard aux écrits dont une personne du royaume de Danemark serait éditeur, fût aussi rendue applicable aux écrits des États étrangers où le droit d'éditeur des sujets du Roi fût réciproquement protégé. ${ }^{65}$

62 A total of four stages can be distinguished in the development of the principle of national treatment. These stages will be discussed at greater length in the course of this study.

63 It was only later, and very rarely, that this limitation was unconditionally abandoned; see the French Decree of 1852 (see para. 84 below). Accordingly, the willingness to grant protection to foreign works or foreign authors was at first mainly rooted in self-interest, cf. Boucher 1932, p. 38: 'elle leur est accordée surtout comme monnaie d'échange et pour pouvoir demander aux Etats étrangers un traitement réciproque en faveur de nos auteurs français.'

64 Recueil des conventions (propriété littéraire) 1904, p. 189; Ladas 1938, p. 22.

65 Romberg 1859, Tome II, p. 139. In Recueil des conventions (propriété littéraire) 1904, p. 189, the following traduction exacte is given:

(...) de rendre, par loi expresse, la défense contenue dans l'ordonnance du 7 janvier 1741 contre la contrefaçon d'œuvres littéraires, mais qui a principalement égard aux écrits dont une personne du Royaume de Danemark a le droit d'éditeur, applicable aux écrits des sujets d'États étrangers où le droit d'éditeur des sujets du Roi est réciproquement protégé.

Darras 1887, p. 191, wonders whether the ordinance is a step backwards rather than forwards, because the Copyright Act of 1741 made no distinction between Danish and foreign authors. In practice, however, this was apparently less clear-cut (Recueil des conventions (propriété littéraire) 1904, p. 189). In 1741, people probably thought only of the domestic situation without taking international aspects into consideration, because this problem hardly existed in the eighteenth century - and afterwards they started to read a distinction into it. 
Example: Prussia 1837. Another important example is the regulation in the Prussian Copyright Act of 11 June 1837. This was a leading international regulation, which even served as a model in France. ${ }^{66}$ Article 38 of this law provided the following:

Auf die in einem fremden Staate erschienenen Werke soll dieses Gesetz in dem Maaße Anwendung finden, als die in demselben festgestellten Rechte den in Unseren Landen erschienenen Werken durch die Gesetze dieses Staates ebenfalls gewährt werden. ${ }^{67}$

Unilateral approach is not satisfactory. Nevertheless, the unilateral approach soon proved unsatisfactory. In the first place, unilateral legislation could not ensure that a country's own works or authors were protected abroad, because they remained dependent on the foreign authorities for that. And stubborn 'pirate countries', which generally produced little literature and art themselves, were quick to take stock of the situation. This is illustrated by the assessment by Veegens (please note that this was written in 1895, when the Netherlands had already been declared a copyright pariah):

For a small country, whose population speaks a language that is not widespread and practises foreign languages diligently, a reciprocal ban on reprinting works published in the other country is more of a disadvantage than an advantage in a material sense. Works written in the Dutch language do not run the risk of being reprinted abroad, except for purposes of distribution to the Flemish population of Belgium. On the other hand, foreign books are read a great deal in the Netherlands and reprinting them, especially if the price is high, can be an advantageous business. ${ }^{68}$

Reciprocity. In the second place, the reciprocity conditions proved difficult to 81 apply in practice and there was the risk of abuse. Reciprocity is, as Villefort observed, 'au point de vue de la législation internationale privée, un principe beaucoup plus fécond en apparence qu'en réalité. Rien n'est plus facile que de l'écrire dans la loi, mais les difficultés deviennent le plus souvent insurmontables (. . .)' ${ }^{6}{ }^{69}$

66 Renault 1878, p. 8; Villefort 1851, p. 18 and p. 53 (who reports that Austria and the United Kingdom, among other countries, followed the example of the Prussian law). This Act was prepared under the guidance of Von Savigny (see note 237 of Chapter 5).

67 Art. 38 of the Prussian Copyright Act of 11 June 1837, see Eisenlohr 1856, pp. 59-60.

68 Veegens 1895, pp. 175-176. Bureau de l'Union, DdA 1891, p. 2:

La petite nation de quelques millions d'habitants est riche; elle a besoin d'une quantité rélativement grande de littérature; celle qu'elle produit elle-même ne lui suffit naturellement pas; aussi a-t-elle l'habitude de s'approprier sans restrictions les trésors littéraires de l'Angleterre, de la France et surtout de l'Allemagne, avec laquelle elle a des affinités de race. L'idée qu'il serait possible de s'imposer des restrictions dans l'usage de cette liberté paraît encore inconcevable en Hollande.

See also Kok 1905 , p. 36 et seq.

69 Villefort 1851, p. 53. 
This was particularly true of reciprocity conditions, like the Prussian one, where it was not only a question of whether protection was granted in the other treaty country but also of ascertaining what protection was granted there - and this gave rise to serious complications. For example, the reciprocity condition of the Prussian provision was hardly ever met in practice. ${ }^{70}$ According to Villefort, such reciprocity conditions were unworkable and a different approach had to be considered:

(...) si la réciprocité légale entre les Etats a toujours été difficile à établir, elle devait lêtre surtout dans une matière aussi délicate, aussi pleine de nuances que la propriété littéraire. Un seul example pris entre mille nous suffira pour rendre claire notre démonstration. (...) Il n'y a donc qu'un moyen pour les nations de garantir avec quelque efficacité la propriété de leurs auteurs, les unes vis-à-vis des autres, c'est de conclure entre elles des conventions diplomatiques; $\left(. . .{ }^{71}\right.$

82 Development stage 2: bilateral treaties. As early as 1837 a French committee of inquiry concluded that the reprinting of French works abroad could in fact be combated only by means of treaties. ${ }^{72}$ Regulation by treaty was a safer alternative, because it allowed the situation in a foreign country to be brought under control. And it might be possible to bring other countries on board by exchanging copyright protection for other trade concessions. So this was what countries embarked on. From 1840 onwards, more and more bilateral treaties were concluded, often called 'conventions pour la garantie réciproque de la propriété des œuvres d'esprit et d'art'. Nearly all these treaties were based on the principle of national treatment: the contracting states agreed to abolish the limitation to national works or authors in relation to each other's works or authors. Regulating national treatment by treaty removed the raison d'être for the reciprocity condition, as it was now mutually agreed to proceed with national treatment of each other's works or authors ('garantie réciproque de la propriété littéraire et artistique'), and a conditional 'offer' was no longer necessary. This was the obvious, second stage in the development of the principle of national treatment: it was raised to treaty level, making it unconditional. ${ }^{73}$

70 Apparently, the provision was understood in practice in such a way that as far as the 'Voraussetzungen des Rechtsschutzes' were concerned, similarity was required (Klostermann 1867, p. 84; Recueil des conventions (propriété littéraire) 1904, p. XIX also perceives reciprocity 'sous la forme difficile à réaliser de l'équivalence matérielle des lois des pays respectifs.'). Because of this requirement, the reciprocity condition was hardly ever met in practice, and this is why the Prussian provision had 'kaum irgend eine practische Bedeutung', according to Klostermann 1867 , p. 84.

71 Villefort 1851, pp. 54-55.

72 Renault 1878, p. 8; Renault 1889, pp. 206-207.

73 For the record, it should be noted that this does not mean that the principle of national treatment applied in full; important exceptions were made; this will be discussed in more detail in Chapter 2. 
Before 1840 the first steps on this path had already been taken within the German Confederation. Under Article 18(d) of the German Confederation Act of 8 June 1815, measures had to be taken within the Confederation to protect authors and publishers against reprinting. ${ }^{74}$ These measures did not materialize, however, and Prussia therefore began making independent treaties with 32 other German states from 1827 onwards. ${ }^{75}$ Here we see the principle of national treatment appearing for the first time in international agreements. ${ }^{76}$ For example, the agreement between Prussia and SchwartzburgSondershausen of 6 October 1827 included the following provision:

(. . .) daß das Verbot wider den Bücher-Nachdruck, so wie solches bereits im ganzen Umfange der Preußischen Monarchie zum Schutz der inländischen Schriftsteller und Verleger, nach den in den einzelnen Provinzen geltenden Gesetzen besteht, auch auf die Schriftsteller und Verleger der Fürstlich-Schwartzburg-Sondershausenschen Lande Anwendung finden, und mithin jeder durch Nachdruck oder dessen Verbreitung begangne Frevel gegen leztern, nach denselben gesetzlichen Vorschriften beurteilt und geahndet werden soll, als handle es sich von beeinträchtigten Schriftstellern und Verlegern der Preußischen Monarchie selbst. ${ }^{77}$

All this still took place within the framework of the German Confederation, but from 1840 onwards, truly international treaties were concluded between sovereign states. With its large production in the field of literature and art, France was at the forefront. ${ }^{78}$ Other countries did not always prove sympathetic, however, and so the French attempts to conclude treaties initially failed to achieve the desired success. ${ }^{79}$ France then took a measure that commanded widespread respect: by Decree of 28 March 1852, it abolished any limitation to national works or authors, without attaching reciprocity conditions. From then on, French law also protected foreign works and authors. ${ }^{80}$ Thus, France

74 Laboulaye 1855, p. 287; Eisenlohr 1856, p. 1; Darras 1887, p. 193.

75 Klostermann 1867, p. 51; Ladas 1938, p. 20.

76 Even earlier, there was the French Decree of 19 June 1811, in which an agreement was made between France and occupied Italy. Art. 2 of this Decree reads as follows:

Les auteurs français et italiens, ainsi que les héritiers des uns et des autres, jouiront réciproquement comme ils étaient nationaux, dans toute l'étendue de notre empire et du royaume d'Italie, des droits d'auteurs assurés par l'article 39 de notre décret du 5 février 1810.

See Darras 1887, p. 190. But this cannot be said to be a truly international agreement.

77 Recueil Martens 1829, pp. 327-329 (no. 66).

78 On the pioneering role played by France, see, inter alia, Kok 1905, p. 27. The United Kingdom was also in the leading group, see Ricketson and Ginsburg 2006, p. 23.

79 Ladas 1938 , p. 27 et seq.

80 Renault 1878, p. 12 et seq.; Darras 1887, pp. 221-302 (p. 250 et seq.); Röthlisberger 1906, pp. 36-37; De Beaufort 1909, p. 54; Ladas 1938, pp. 27-29 and p. 46; R. Plaisant 1945, p. 151. In practice, however, the Decree was interpreted less generously (this is discussed in para. 143 below). 
proclaimed the principle of national treatment unilaterally and - which was new - unconditionally. In this way France decided to set a good example in the hope of more cooperation from other countries. ${ }^{81}$

85 Indeed, the mood changed in the second half of the nineteenth century and countries began to take the fight against international reprinting more seriously. ${ }^{82}$ The French Decree proved to be a major boost for international copyright and released a flood of international agreements all over Europe. ${ }^{83} \mathrm{At}$ the heart of nearly all these agreements was the principle of national treatment; there was usually little or no uniformization of substantive copyright rules. Sometimes these agreements were independent copyright treaties, sometimes they were rules included in other treaties, such as trade and friendship treaties; for example, copyright protection was exchanged for other concessions. ${ }^{84}$ The Netherlands, too, entered into a number of bilateral treaties, albeit reluctantly. ${ }^{85}$

81 'Quand nous aurons commencé par déclarer que la contrefaçon chez nous est un délit puni par les lois, je crois que nous obtiendrons beaucoup plus facilement des gouvernements qu'ils l'abolissent chez eux', said Barthélemy Saint-Hilaire in the French Parliament in 1851, see Renault 1878, p. 11; Renault 1889, p. 207. Cf. also Boucher 1932, p. 32. Ricketson and Ginsburg 2006, p. 23, describe the French attitude as 'one of "pragmatic altruism", that is, using its generosity towards foreigners as a means of "shaming" countries to which those persons belonged into taking action.'

82 Ricketson and Ginsburg 2006, p. 23.

83 The French Decree gave an important boost to treaty law (cf. Ladas 1938, p. 27), but the example it set was not copied on a large scale in the national legislation of other countries. In 1886 Belgium converted to a unilateral and unconditional principle of national treatment (Art. 38 of the Belgian Copyright Act 1886, cf. Wauwermans 1894, p. 390) and in 1898 Luxembourg followed (Art. 39 of the Luxembourg Copyright Act of 10 May 1898, cf. Recueil des conventions (propriété littéraire) 1904, p. 369). Cf. also Weiss 1908, p. 275, note 2. Even so, in an Act of 5 March 1921, Belgium introduced a material reciprocity exception:

En outre, s'il est constaté que les auteurs belges ne jouissent dans un pays étranger que d'une protection moins étendue, les ressortissants de ce pays ne pourront bénéficier que dans la même mesure des dispositions de la présente loi pour leurs œuvres publiées à l'étranger.' See Bureau de l'Union, $D d A$ 1921 (Belgique), pp.13-15 and pp. 97-98; and Art. 79 of the present Belgian Copyright Act of 30 June 1994.

84 See e.g. para. 123 below. Even today, international rules on intellectual property are still linked to trade agreements, notably the TRIPS Agreement, an intellectual property regime established under the auspices of the World Trade Organization WTO (see para. 14 above). The TRIPS Agreement is therefore not new in this respect, as is sometimes wrongly claimed (see e.g. Ricketson 1995, p. 872 et seq.).

85 See, inter alia, De Beaufort 1909, p. 65 et seq. Before the Berne Convention entered into force in the Netherlands on 1 November 1912, the Netherlands had concluded three bilateral copyright treaties with France, Belgium and Spain. With France, it was agreed in a trade and shipping treaty of 25 July 1840 that a separate treaty would regulate ownership of literary works (Stb. 1841, 23; art. 14). Years later, on 27 May 1852, a treaty of this kind was indeed signed, but it was rejected by the Dutch House of Representatives; text in Recueil Lagemans, Tome IV, 1859, pp. 52-54 (no. 285). Finally, on 29 March 1855, a treaty with France was signed (Stb. 1855, 107, see also Stb. 1860, 19). Pursuant to Art. 11, its fate depended on the fate of the trade treaty of 1840 . Thus, what happened was that it was suspended in 1882, when negotiations on economic relations between the Netherlands and France had failed (JDI 1884, p. 325; Pouillet, Maillard and Claro 1908, p. 955; Lyon-Caen and Delalain 1889, Tome II, p. 331 and p. 336). By declaration of 19 April 1884, exchanged in the framework of a trade treaty of the same date, the treaty, pending a final settlement and with some extensions, was reactivated (Stb. 1885, 176). This treaty is no longer in force today (Stuyt 1953, p. 39). 
Guiding principle. Thus, the principle of national treatment became the guiding principle in international copyright law. It was enshrined in many national copyright laws and governed virtually all bilateral treaties.

\subsubsection{Analysis of the principle of national treatment}

Two aspects. Armed with the previously gained insights into the state of lawlessness, we will now take a closer look at the solution of the principle of national treatment. We have seen that the state of lawlessness encompasses two aspects: an aliens-law aspect (discrimination) and a conflict-of-law aspect (legal vacuum). The principle of national treatment put an end to this state of affairs by bringing foreign works or authors, as if they were of national origin, under the wing of national law by 'treating' them nationally. ${ }^{86}$ Thus, it ended the legal vacuum in which these works or authors had found themselves and put an end to their discrimination. It terminated the state of lawlessness - and with it the two aspects contained therein. As a result, the principle of national treatment, mirrorwise, also has these two aspects: it substitutes an applicable law for the previous legal vacuum, and it substitutes non-discrimination for the previous discrimination.

Exactly how did this work? Well, the principle of national treatment opposed the usual limitation to national works or national authors. The principle of

On 30 August 1858 an 'agreement to guarantee the ownership of scientific and literary works' was concluded with Belgium (Stb. 1859, 11 and 14). The Netherlands had an interest in that, namely the protection of its own authors and works in the Dutch-speaking part of Belgium; one could think of the remark by Veegens (see para. 80 above). This treaty is no longer in force either (Stuyt 1953, p. 40). Finally, on 31 December 1862, a treaty was also concluded with Spain 'to prevent the reprinting of scientific and literary works' (Stb. 1863, 115). As early as 1880, it was denounced and on 4 October 1882 it was rendered inoperative permanently (De Beaufort 1909, p. 66; Recueil des conventions (propriété littéraire) 1904, p. 213). A treaty was negotiated with Germany. Following long insistence by the German government and 'protracted negotiations', a treaty was concluded with Germany on 13 May 1884 (text in: Recueil Lagemans, Tome IX, 1886, pp. 81-88 (no. 686)). It provided for more generous protection than the previous bilateral treaties concluded by the Netherlands. This met with opposition in the Netherlands (Veegens 1895, pp. 184-186). Moreover, this more generous protection would have an impact on relations with Belgium through the most-favoured-nation clause in Art. 12(5) of the Dutch-Belgian treaty from 1858. In the end, without debate or vote, the treaty was not ratified by the Netherlands (Bureau de l'Union, DdA 1891, p. 2; Veegens 1895, p. 186; Kok 1905, p. 28; De Beaufort 1909, p. 66), whereas German had already ratified it on 19 June 1884. In addition to such bilateral treaties, trade, shipping and friendship treaties occasionally contained one or two provisions on copyright. There is also the Proclamation of 20 November 1899 by the President of the United States. Thanks to this unilateral proclamation, Dutch authors enjoyed copyright protection in the United States under certain conditions (text in Recueil Lagemans, Tome XIV, 1901, p. 141 (no. 903); see also the Proclamations of 9 April 1910 and 26 February 1923 (CB 1949, p. 140, Tableau critique des traités), and the exchange of diplomatic notes of 3 April 1923 between the Netherlands and the United States on copyright on musical works (SDN1921, p. 176 et seq.)).

86 Cf. Section 3 of the British International Copyright Act of 1844, $7 \& 8$ Vict. c. 12: 'in such and the same manner as if such books were first published in the United Kingdom'. 
national treatment, as we have seen, also arose in the unilateral legislation as a mirror image of this limitation ('our law shall also apply to foreign works if the law of the foreign country in question applies to our works') - hence the problem of lawlessness and the solution of national treatment as two sides of the same coin. This limitation was, as explained earlier, either a delimitation of the scope of application of national law or a restriction on the legal capacity of foreigners.

89 Limitation as delimitation. Where it concerned a delimitation of the scope of national law, as in most cases, ${ }^{87}$ there were a total of three delimitations of this scope: the two delimitations arising from the principle of formal territoriality and the delimitation to national works or authors; as we have seen, it was the combination of these delimitations that caused the state of lawlessness. In this configuration, the principle of national treatment eliminated one of these delimitations - namely the delimitation to national works or national authors and thus extended the scope of national law to foreign works or foreign authors. In other words, the legal vacuum was filled by extending the scope of the territorially applicable law (in terms of both formal and material territoriality). Accordingly, the principle of national treatment brought foreign works or foreign authors under the scope of the principle of formal territoriality. This made the formal territoriality principle complete. Compare the following consideration of the Italian Corte di cassazione on the principle of national treatment:

Le principe fondamental (...) consiste à étendre aux auteurs d'œuvres publiées à l'étranger (...) la protection de la loi nationale de chaque pays.

(... ) l'auteur peut exercer le droit lui appartenant, conformément aux principes et aux sanctions que consacre la loi de l'État où il entend le faire valoir, car c'est dans cette loi seule que le juge puise sa propre jurisdiction et c'est elle seule qu'il est en mesure d'appliquer. ${ }^{88}$

90 Thus, the principle of national treatment is the culmination and at the same time the anchorage of the principle of formal territoriality in international

87 See section 1.1.2 under (a).

88 Corte di cassazione 14 January 1900, Monitore dei Tribunali, Vol. 41, 1900, II series, vol. 3, pp. 176-177 (Albrecht, Meister and Gualassini):

Il principio fondamentale (...) consiste nell'estendere agli autori (...) delle opere composte e pubblicate all'estero, la protezione della legge nazionale di ciascun paese. (...) può l'autore esercitare il diritto che gli spetta giusta le norme e le sanzioni portate dalla legge dello Stato nel quale intende farlo valere, poichè da essa legge e non da altra il magistrato giudicante attinge la propria giurisdizione, ed casa legge e non altra egli è in grado di applicare.

French translation in $D d A 1900$, p. 121. This judgment was discussed earlier (see note 40 of this Chapter 1) because it expresses so clearly the formal-territorial nature of copyright. 
copyright law. Consequently, the principle of national treatment in this configuration is primarily a conflict-of-law solution. At the same time, however, it is also an aliens-law solution: because the territorially applicable law (in terms of both formal and material territoriality) is declared applicable not only to national works or authors, but now also to foreign works or authors, the latter are no longer discriminated against.

Restriction on legal capacity. In the other configuration - which occurred in some cases - the limitation to national authors was not designed as a delimitation of the scope of national law but as a restriction on the legal capacity of foreigners. We have already observed that the legal vacuum arose in this configuration as well. ${ }^{89}$ In these cases, too, the principle of national treatment - albeit by a different route - brought about the same aliens-law solution and the same conflict-of-law solution. In the first instance, it ensured non-discrimination: the foreign author acquired legal capacity and could be the bearer of copyright, which means that in this configuration there was primarily a remedy under aliens law. But this immediately raised the question of the applicable law: if the foreign author can be a bearer of copyright, which law applies to the protection of his works? That question could not be left unanswered, because then no solution would have been reached: if the foreign author is granted legal capacity but subsequently no applicable law is designated (thus leaving him in the legal vacuum), the state of lawlessness is not terminated. The question of the applicable law was therefore answered, in the same breath and - of course - entirely in line with the scope of application already defined (for national authors), by the general conflict-of-law principle of the time: the principle of formal territoriality. However, as we saw before, in practice the limitation to national works or authors was usually not a question of legal capacity, but rather a delimitation of the scope of national law. Consequently, the conclusion is justified that the principle of national treatment was in fact primarily a conflict-of-law solution.

Synthesis. In any event, whatever the limitation applied - be it a delimitation of the scope of national law or a restriction on the legal capacity of foreign authors - the solution of the principle of national treatment was the same: from a conflict-of-law point of view, the legal vacuum was eliminated and an applicable law was designated on the basis of the principle of formal territoriality, and from an aliens-law point of view, the principle of non-discrimination was proclaimed. Thus, the principle of national treatment contains two rules:

89 See section 1.1.2 under (b). 
a conflict-of-law rule and an aliens-law rule. That is how it was designed and as such it was recognized; for example, Bastide described the principle of national treatment as a solution '(...) qui résout ce conflit de lois en appliquant la législation du pays d'importation et en assimilant l'étranger au national de ce pays (...). ${ }^{90}$

93 These two rules are, as may be seen from the foregoing, so intertwined with each other that they actually form one whole. ${ }^{91}$ They are inherent to each other.

94 Conflict-of-law regarded as self-evident at the time. And so the remark made by Darras quoted earlier falls into place: 'une des conséquences forcées de l'assimilation est de rendre applicables à tout délit les lois du pays de la contrefaçon; cela est évident et aucune dérogation n'a été apportée à cette déduction logique. ${ }^{92}$

95 Evident, logical and never challenged: so self-evident was the conflict-of-law meaning of the principle of national treatment for people in the nineteenth century.

96 Current conceptual obfuscation. This brings us to a remarkable instance of conceptual obfuscation that took place in the course of history: while the conflictof-law rule in the principle of national treatment was completely self-evident for people in the nineteenth century, nowadays this conflict-of-law rule is no longer understood. Below, this phenomenon will be referred to as 'conceptual obfuscation'.

97 Problem of self-evidence. One of the causes of this conceptual obfuscation lies in the circumstance that the conflict-of-law solution of the principle of national treatment (applicability of domestic law) was completely self-evident to people in the nineteenth century and that, given the dominance of the principle of formal territoriality at the time, this solution was not at all special to them either. That is why nineteenth-century literature paid hardly any attention to the conflict-of-law side of the principle of national treatment.

90 Bastide 1890, p. 98 (underlining added). See also Celliez 1878; Renault 1878, pp. 30-31; Fliniaux 1879, p. 32 et seq.; Pouillet 1894, p. 791 (no. 859).

91 Cf. Kosters 1917, p. 75.

92 Darras 1887, p. 606. See para. 3 above. For example, the term 'assimilation' was used for both aspects of the principle of national treatment. Cf. also Renault 1878, p. 31; Clunet 1887, p. 46; Bastide 1890, p. 98; Pouillet 1894, p. 791 (no. 859); Bureau de l'Union, DdA 1895, p. 162. 
It was, in the words of Darras, self-evident, logical and never challenged. And one can remain silent about something that is a matter of course. This silence is now avenging itself: nineteenth-century sources do not offer us much guidance. Thus, the self-evidence of the time is a cause of the present-day misunderstanding. How tragic is the fate of this conflict-of-law rule: once undiscussed because it spoke for itself, now misunderstood because it remained undiscussed.

Paradigm shift. But the actual cause of the conceptual obfuscation is a paradigm shift and a changed perspective. Our current thinking about the conflict of laws is no longer determined by the doctrine of statutes but by Von Savigny's model, and we approach the problem at hand from that other, Savignian perspective. We look at a statutist problem and the corresponding statutist solution through Savignian glasses, and this creates a distorted picture - our field of view has been narrowed by Von Savigny. As a result, we no longer see the conflict-of-law rule in the principle of national treatment. In addition, we are not aware that we are looking through Savignian glasses, which makes the conflict-of-law rule in the principle of national treatment elusive for us. To understand this conflict-of-law rule properly, we must therefore consciously switch to a different way of thinking about the conflict of laws, a way of thinking based on another conflict-of-law system, namely the pre-Savignian statutist theory.

Examination of the conceptual obfuscation in Part II. We will not pursue this conceptual obfuscation - and specifically the question why we no longer understand the conflict-of-law rule - any further at this stage. This will be dealt with in detail in Part II. ${ }^{93}$ In this Part I we will concentrate on the further genesis of the principle of national treatment.

Examples in international agreements. In the context of the analysis of the 100 conflict-of-law rule in the principle of national treatment, let us take a closer look at a few more examples.

See, for example, the treaty between Prussia and Schwartzburg-Sondershausen of 1827, which was discussed above. This is one of the oldest treaties:

(...) daß das Verbot wider den Bücher-Nachdruck, so wie solches bereits im ganzen Umfange der Preußischen Monarchie zum Schutz der inländischen Schriftsteller und 
Verleger, nach den in den einzelnen Provinzen geltenden Gesetzen besteht, auch auf die Schriftsteller und Verleger der Fürstlich-Schwartzburg-Sondershausenschen Lande Anwendung finden, und mithin jeder durch Nachdruck oder dessen Verbreitung begangne Frevel gegen leztern, nach denselben gesetzlichen Vorschriften beurteilt und geahndet werden soll, als handle es sich von beeinträchtigten Schriftstellern und Verlegern der Preußischen Monarchie selbst. ${ }^{94}$

102 The German Federal Resolution of 1832, which laid down the principle of national treatment for all the states of the German Federation, stated:

(...) daß bei Anwendung der gesetzlichen Vorschriften und Maßregeln wider den Nachdruck, der Unterschied zwischen den eigenen Unterthanen eines Bundesstaates und jenen der übrigen, in deutschen Bunde vereinigten Staaten gegenseitig und im ganzen Umfange des Bundes in der Art aufgehoben werden soll, daß die Herausgeber, Verleger und Schriftsteller eines Bundesstaates sich in jedem andern Bundesstaate des dort gesetzlich bestehenden Schutzes gegen den Nachdruck gleichmäßig zu erfreuen haben werden. ${ }^{95}$

103 The treaty between France and Hanover of 1851 provided the following:

Le droit exclusif des auteurs de publier leurs ouvrages d'esprit ou d'art, tels que (...), sera protégé réciproquement dans les deux États, de telle sorte que la réimpression et la reproduction illicites des œuvres publiées primitivement dans l'un d'eux seront assimilées dans l'autre à la réimpression et à la reproduction illicites des ouvrages nationaux; et dès lors, toutes les lois, ordonnances et stipulations aujourd'hui existantes ou qui pourraient par la suite être promulguées au sujet du droit exclusif de publication des œuvres littéraires et artistiques, seront applicables à cette contrefaçon. ${ }^{96}$

104 Another clear example is the Dutch-French treaty of 1852, which never entered into force:

Le droit de propriété des auteurs d'ouvrages scientifiques et littéraires s'exercera simultanément sur le territoire des deux pays, de telle sorte que la reproduction ou la contrefaçon dans l'un des deux Etats, d'ouvrages publiés dans l'autre Etat, soit assimilée à celle des ouvrages de la même nature, originairement publiés dans l'Etat même, et donne lieu, en faveur desdits auteurs ou ayant-cause, à l'application de toutes les lois, ordonnances ou règlements, qui dans ce même Etat garantissent actuellement, ou

94 Treaty on the protection of copyright between Prussia and Schwartzburg-Sondershausen, published by Prussian declaration of 6 October 1827, Recueil Martens 1829, pp. 327-329 (no. 66); underlining added.

95 Federal resolution of 6 September 1832. See Eisenlohr 1856, p. 1, and Laboulaye 1855, p. 287; Klostermann 1867, p. 52; Darras 1887, p. 194 (underlining added).

96 Art. 1 of the treaty between France and Hanover of 20 October 1851, Recueil Delalain 1866, p. 24 (underlining added). 
garantiront par la suite aux producteurs nationaux le droit exclusif de publier leurs œuvres. ${ }^{97}$

An important example is the Franco-Prussian treaty of 1862 , which many

German states joined:

Les auteurs (...) jouiront dans chacun des deux États récriproquement des avantages qui y sont ou y seront attribués par la loi à la propriété des ouvrages de littérature ou d'art, et ils auront la même protection et le même recours légal contre toute atteinte portée à leur droits, que si cette atteinte avait été commise à l'égard d'auteurs d'ouvrage publiés pour la première fois dans le pays même. ${ }^{98}$

This wording was adopted almost literally by the successor to this treaty, the Franco-German treaty of $1883 .{ }^{99}$ And, in turn, this Franco-German treaty of 1883 was a model for the Berne Convention. Thus, early on, the outlines of the wording that was to be adopted in the Berne Convention were visible.

Examples in unilateral treaties. In unilateral treaties the conflict-of-law solution of the principle of national treatment often came out clearly as well. Here, too, let us look at some examples from many. ${ }^{100} \mathrm{~A}$ case in point is the Danish ordinance of 1828, cited above, which is regarded as the first unilaterally proclaimed principle of national treatment:

(...) que la défense contenue dans l'ordonnance du 7 janvier 1741 contre la contrefaçon, mais qui a spécialement égard aux écrits dont une personne du royaume de Danemark serait éditeur, fût aussi rendue applicable aux écrits des États étrangers où le droit d'éditeur des sujets du Roi fût réciproquement protégé. ${ }^{101}$

The Norwegian law of the same year provided the following:

Les règlements sur la contrefaçon en vigueur dans ce royaume seront applicables aussi aux écrits dont les sujets d'Etats étrangers auront le droit de publication; (...) Cette

97 Art. 1 of the Dutch-French treaty of 27 May 1852, see Recueil Lagemans, Tome IV, 1859, pp. 52-54 (no. 285); underlining added. The treaty was denounced by the Dutch House of Representatives; see note 85 of this Chapter 1.

98 Art. 1 of the French-Prussian treaty of 2 August 1862, Recueil Martens 1874, pp. 306-314 (no. 43); underlining added.

99 Art. 1 of the French-German treaty of 19 April 1883, Recueil des conventions (propriété littéraire) 1904, p. 70. This treaty will be further discussed below, cf. also para. 178 below.

100 The French law is disregarded here because there were too many divergent interpretations about that, cf. Foelix 1844.

101 Ordonance of 7 May 1828, Romberg 1859, Tome II, p. 139 (underlining added), see para. 78 above. 
loi sera en vigueur seulement à l'égard des États dans lesquels il est ou sera défendu de reproduire des écrits, édités par des sujets norwégiens. ${ }^{102}$

109 The leading Prussian Copyright Act of 1837, which was discussed earlier, included the following provision:

Auf die in einem fremden Staate erschienenen Werke soll dieses Gesetz in dem Maaße Anwendung finden, als die in demselben festgestellten Rechte den in Unseren Landen erschienenen Werken durch die Gesetze dieses Staates ebenfalls gewährt werden. ${ }^{103}$

110 The Austrian Copyright Act of 1846 provided the following:

Den im Auslande ausser dem (früheren) Deutschen Bundesgebiete erschienenen Werken wird der in diesem Gesetze ausgesprochene Schutz in dem Masse gewährt, als die diesfälligen Rechte den in dem k.k. österreichischem Gebiete erschienenen Werken durch die Gesetze des fremden Staates gleichfalls gesichert sind. ${ }^{104}$

\section{A Swedish law of 1867 provided the following:}

Die Bestimmungen diese Gesetzes können unter der Voraussetzung der Gegenseitigkeit ganz or teilweise vom König als gleichfalls anwendbar auf die Nachbildung von Erzeugnissen fremder Künstler die sich ausser Reiches befinden, erklärt werden. ${ }^{105}$

112 Finally, the Italian Copyright legislation dating from 1882, provided the following:

Vorliegendes Gesetz ist anwendbar auf Urheber, deren werke in auswärtigen Ländern veröffentlicht sind, mit denen besondere vertrage nicht oder nicht mehr bestehen, vorausgesetzt, dass bei ihnen Gesetze bestehen, welche zu Gunsten der Autoren mehr oder weniger ausgedehnte Rechte anerkennen, und dass diese Gesetze durch Reziprozität auf Werke anwendbar sind, welche im Königreich Italien veröffentlicht sind. ${ }^{106}$

102 Act of 13 September 1828 (underlining added). Romberg 1859, Tome II, p. 224. According to Recueil des conventions (propriété littéraire) 1904, p. 379, this Act dates from 13 September 1830. In any event, Ladas's observation that the Greek law of 1833 is the second oldest is therefore erroneous. (Ladas 1938, p. 23; see also note 108 of this Chapter 1 ).

103 Art. 38 of the Prussian Copyright Act of 11 June 1837 (underlining added), Eisenlohr 1856, pp. 59-60; see para. 79 above.

104 Art. 39 of the Act of 19 October 1846 (underlining added), see Gesetze über das Urheberrecht 1891, p. 36.

105 Art. (2) of the Act of 3 May 1867 (underlining added). German translation in Gesetze über das Urheberrecht 1891, p. 165.

106 Art. 44 of the Royal Decree of 19 September 1882 (underlining added). German translation in Gesetze über das Urheberrecht 1891, p. 60. 
Conditional principle of national treatment. Finally, we will briefly consider the conditional principle of national treatment as contained in the unilateral laws: national treatment was not granted until a condition of reciprocity had been satisfied. This condition of reciprocity was structured in different ways. ${ }^{107} \mathrm{It}$ could be a 'formal-reciprocity condition', that is a reciprocity condition without substantive requirements ("if you apply your law to our works, we will apply our law to your works'). The Norwegian law cited above is an example of this. It could also be a 'material-reciprocity condition', which did involve substantive requirements, for example, an absolute requirement ('our law applies to your works if your law guarantees equal protection to our works') ${ }^{108}$ or a relative requirement ('our law applies to your works to the extent that your law applies to our works'). ${ }^{109}$ Whatever reciprocity condition was imposed, no national treatment was applied if this condition was not met. ${ }^{110}$ The foreign work or the foreign author would then remain imprisoned in his state of lawlessness, in the discriminatory legal vacuum. Specifically, there was a conditional conflict-oflaw rule ('the scope of our national law will be extended to your works if you do the same thing the other way around') and a conditional non-discrimination principle ('we do not discriminate if you do not do so either').

Treaty level. The reason for making the principle of national treatment subject to a condition of reciprocity was no longer relevant - as we have already seen - where this principle was elevated to the level of a treaty. ${ }^{111}$ Thus, in the second stage of its development, the principle of national treatment became unconditional; the principle as such was no longer linked to reciprocity conditions - a step made possible by its new embedding: in a treaty. ${ }^{112}$

107 Reciprocity will be discussed in more detail in section 6.2.2.

108 The Greek law of 1833 could be mentioned as an example of that. It attached the following condition to the Greek prohibition against reprinting: 'Les dispositions de l'article précédent s'appliquent en outre: 1. en faveur de l'étranger, même n'ayant pas obtenu de privilège en Grece, mais seulement dans le cas où la puissance à laquelle appartient cet étranger accorde la même protection au sujet hellène; (. . .)', Recueil des conventions (propriété littéraire) 1904, p. 327. Cf. also Romberg 1859, Tome II, p. 186.

109 The Prussian legislation of 1837 is an example of that: '(...) soll dieses Gesetz in dem Maaße Anwendung finden (...)', see para. 79 above. In practice, as already noted in note 70 of this Chapter 1, this provision was apparently understood in such a way that similarity was required with regard to the 'Voraussetzungen des Rechtsschutzes'. This is an absolute requirement - a requirement which implied that the condition of reciprocity was hardly ever met in practice.

110 In the case of a relative reciprocity condition: to the extent that this condition was not met, national treatment was not applied.

111 See para. 82 above.

112 A rare exception was the French Decree of 1852, in which unconditional treatment was proclaimed unilaterally; see note 63 of this Chapter 1. 


\subsubsection{Summary}

115 Problem and solution. Let us briefly summarize the above discussion on the origin and operation of the principle of national treatment. In the first half of the nineteenth century, the state of lawlessness of foreign works or authors - the discriminatory legal vacuum - was increasingly perceived as problematic. The principle of national treatment was developed as a remedy.

116 Operation: double solution. The principle of national treatment put an end to the state of lawlessness by placing foreign works or authors, as if they were of national origin, under the wing of national law - by treating them 'nationally'. This state of lawlessness has both an aliens-law aspect (discrimination) and a conflict-of-law aspect (legal vacuum), and the principle of national treatment mirrored these two aspects. By means of the principle of formal territoriality, it substitutes an applicable law for the previous legal vacuum (conflict of laws) and substitutes non-discrimination for the previous discrimination (aliens law). Thus, the principle of national treatment embodies two intertwined rules: a conflict-of-law rule and an aliens-law rule.

117 Stages of development. So far, we have distinguished two of the four stages in the development of the principle of national treatment.

118 In the first stage, the principle of national treatment was unilaterally proclaimed in national law subject to the condition of reciprocity: national treatment was applied only if the condition of reciprocity had been met. Many nineteenth-century copyright laws included a principle of national treatment of this kind.

119 This unilateral approach proved unsatisfactory, however, because it did not offer sufficient security and the reciprocity conditions caused many complications. A different approach was adopted and so the second stage in the development of the principle of national treatment emerged: countries began to conclude bilateral treaties in which they ensured national treatment of each other's works or authors. After the middle of the nineteenth century, there came a flood of bilateral treaties, nearly all of which were based on the principle of national treatment.

120 Thus, in its second stage of development, the principle of national treatment was elevated to the status of a treaty, and this meant that there was no longer any reason for making national treatment subject to reciprocity conditions. 
The principle of national treatment became unconditional. Nevertheless, during this second stage, the principle of national treatment did not yet apply in its entirety: important exceptions were made, which will be discussed in Chapter 2. 